a chronic ulcer with indurated edges and no disposition to heal, and glandular enlargement comes late in the course of the disease. All these diagnostic points should be taken into consideration, as was done in this case, before a final amputation is made. A competent microscopist can settle the question by a careful examination of a section of the tumor.

Treatment.-As the prognosis of the disease is always grave, $I$ told the patient after the diagnosis had been made positively that the disease would progress from bad to worse and that there was no hope for recovery from local or constitutional treatment, and that his only chance would be immediate removal of the organ. He had heard the siren tale of all the quacks; in fact, he had tested some of their wares at enormous expense and pain to himself, only to see the disease progress with more rapidity than before; hence he was reconciled to radical and rational treatment, and when $I$ assured him that the element of pain would not enter into the case at all he readily consented to an amputation of the organ, which was done in the following manner:

Operation: The pubis and scrotum were shaved and thoroughly cleansed with soap, water and the usual antisepties. The mechanical cleansing liad been done previously. The head of the organ was thoroughly hooded so as to prevent the possibility from infection from the ulcer during the operative proceedings. A strong rubber band was rendered aseptic, doubled on itself, and thrown around the penis, close to the symphysis pubis. The penis was firmly held, though not stretched, and after a cuff of healthy skin had been dissected back the cut was made through the corpora cavernosa about two inches proximal to any evidence of the diseased tissue and a beveled incision made which left the urethral portion one inch longer than the corpora; the diseased portion was thus ablated. At this point the rubber band was loosened and four small vessels were either twisted or ligated with catgut. The urethra was split up for a small distance and its edges stitched to the skin, which had previously been approximated over the amputated stump of the penis. A soft rubber catheter was left in the bladder in order that the wound might not become infected by the urine passing over it. "A light sterilized gauze dressing and $\mathrm{T}$ bandage were applied to the perineum. The parts were occasionally washed off with boracic acid or carbolic acid solution.

Result.-An uninterrupted recovery was the result and no recurrence of the trouble has appeared, though seven years have elapsed since the operation was performed.

Remarks.-In neglected cases in which the disease has progressed even to the roots of the penis and in which the in guinal glands are enlarged, it becomes necessary to enucleate the glands from the groin as well as to amputate the penis from the symphysis pubis; as a matter of course this is a much more serious operation and the liability to recurrence is much more probable. Castration of the patient at the time this amputation is done has been advocated by some surgeons, but as the operation is required at an age in which sexual passion rarely enters into the case, it occurs to me that the testicles may be left unless they too are involved in the diseased process.

\section{INTESTINAL PARASITES IN CANAL ZONE.} ONE HUNDRED AND FIFTY CONSECUTIVE EXAMINATIONS OF STOOLS.

\section{NORMAN E. WILLIAMSON, M.D. \\ Pathologist, Colon Hospital.

$$
\text { CANAL ZONE. }
$$

Balantidium coli, or Paramacium coli, has not hitherto been reported from this section. It occurred in two cases of our short series. It has also twice been seen by Dr. E. P. Beverley, and in one case by Dr. Lloyd Noland, at Ancon Hospital-five cases in all.

It is oval or pear-shaped, at times round; from 70 to 110 microns in length by from 60 microns to 72 microns in width. It is actively motile, being covered with flagellæ most numerous at the mouth, which is at the small pole. There are a rather large nucleus and two contractile vacuoles.

Intestinal Parasites Fotid is 150 Consecutre Examinatrons OF STOOLs.

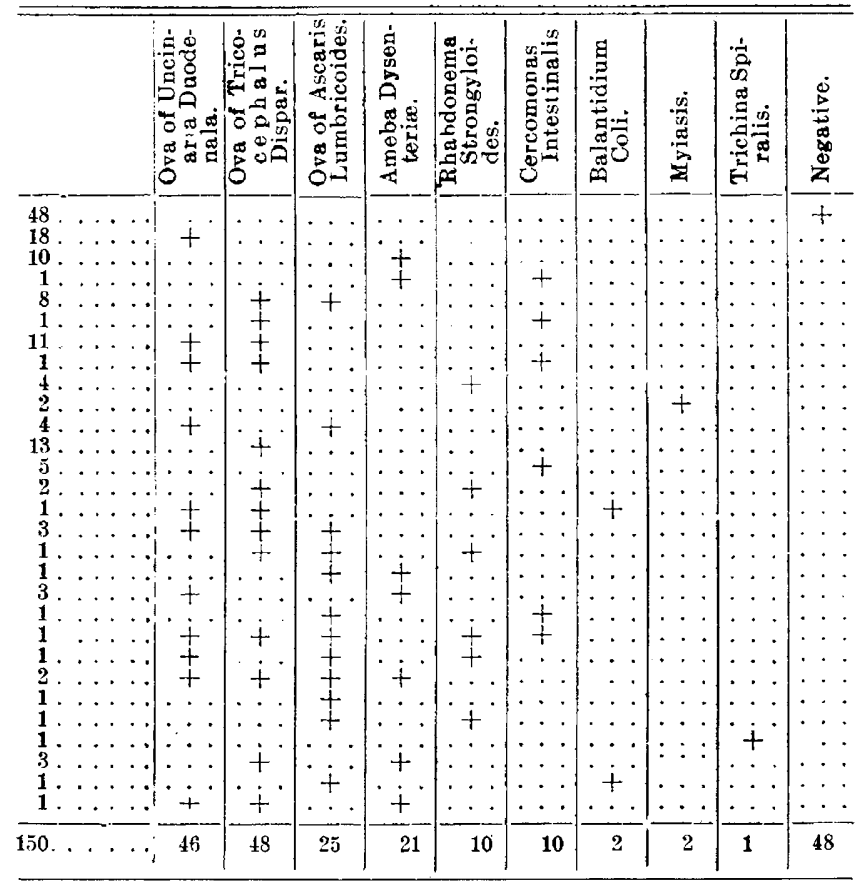

A monograph of reported cases has recently been written by R. P. Strong. ${ }^{1}$ Access to more recent literature is not available here.

The two cases seen here wcre complicated by other infections. Both patients, howerer, had diarrhea, which could be attributed to the balantidium, which was found in great numbers in both cases.

Worthy of note also is the relative frequency of Rhabdenema strongyloides. The small, yellow, slowly motile ameba, which I have frequently seen in the Plijlippines, and which is usually considered non-pathogenic. has not been seen in this series of cases.

\section{A CHRISTMAS STORY.}

\section{E. S. McKEE, M.D. CINCINNATI}

About eighteen years ago I was called to see a patient, a recent arrival from Russia, whom we will call Mrs. Blankstein. She was very ill, indeed, and $I$ found it necessary to see her every day for a month, commencing December 15 . She recovered, and in due time $I$ sent my bill. In somewhat overdue time her husband came to my office to pay it. The following was his plea: "Mr. Doctor: dat bill you zendt mein vife, le's all dright, but vone dem visits you make mein vife you makes him on a Grisdmas day, and I vandt you make me a bresent dat visit you makes mein vife ond Grisdmas day." The request was so original, coming from the source it did, so different from the usual demand of a per cent. off, that I threw off the visit, made him a "bresent" of it, instead of charging him double as I felt like doing for being taken away from my Christmas turkey.

I have had many times the worth of the presented visit telling it to my friends. Almost every Christmas since this occurrence I have been called to some sufferer, poor in this world's goods, and before leaving I have told the story of the Christmas present of a visit and made the patient a present of the Christmas visit I was then making. The happy smile, the brightened eye of the pale patient has been my reward for working when the rest of Christianity was feasting.

1. Bulletin No. 26, Bureau of Gorernment Laboratories, Manila. 